\title{
REPRESENTASI NILAI KEMANUSIAAN WEB SERIES KISAH CARLO (Analisis Semiotika dalam perspektif Charles Sanders Peirce)
}

\author{
Michael Jibrael Rorong*
}

Ilmu Komunikasi, Universitas Putera Batam

\begin{abstract}
ABSTRAK
Simbol, makna dan representasi sangat penting dalam pembentukan makna, setiap aspek yang terkait dengan pembentukan simbol mencerminkan masalah yang begitu kompleks untuk ditafsirkan, kisah carlo adalah seri web yang membentuk aspek transendental dengan ukuran nilainilai kemanusiaan, ini tercermin dari setiap adegan yang dilakukan pada setiap cuplikan video dalam cerita carlo ini yang menunjukkan makna dan nilai kemanusiaan melalui tanda dan penanda yang disampaikan. Penelitian ini menggunakan pendekatan penelitian kualitatif dengan teori dan teknik analisis data yang berpijak pada konstruktivis paradiqma dan perspektif Charles Saunder Peirce, untuk melihat tanda-tanda dan penanda dalam menafsirkan realitas sosial yang mencerminkan nilai-nilai kemanusiaan yang ditemukan dalam fenomena serial web yang ditampilkan dalam cerita serial Carlo. makna dan representasi nilai-nilai manusia sebagai level tertinggi dalam level makna dalam seri web cerita carlo.
\end{abstract}

Kata kunci: Semiotika, Kisah Carlo, Charles Sanders Peirce, Kualitatif, Nilai Kemanusiaan

\section{ABSTRACT}

Symbols, meanings and representations are very important in the formation of meaning, every aspect related to the formation of a symbol reflects a problem that is so complex to interpret, the story of carlo is a web series that forms a transcendental aspect to the measure of human values, this is reflected from each scene performed on each video footage in this carlo story that shows the meaning and value of humanity through the signs and markers conveyed. This study uses a qualitative research approach with theories and techniques of data analysis that stand on constructivist paradiqma and the perspective of Charles Saunder Peirce, to see signs and markers in interpreting a social reality that reflects human values found in the web serial phenomenon Carlo's story show the meaning and representation of human values as the highest level in the level of meaning in the carlo story web series.

Keywords: Semiotic, Carlo's Story, Charles Sanders Peirce, Qualitative, Value of Humanity

${ }^{*}$ Korespondensi Penulis

Email: michael.rorong@puterabatam.ac.id 


\section{PENDAHULUAN}

Indonesia merupakan Negara yang sangat produktif dan mendukung terhadap berkembangnya teknologi bahkan salah satu pengguna media sosial terbesar di dunia. Indonesia sendiri, mengungkapkan pengguna internet di Indonesia saat ini mencapai 63 juta orang. Angka tersebut, 95 persennya menggunakan internet untuk mengakses jejaring sosial.

Era globalisasi, perkembangan telekomunikasi dan informatika (IT) sudah begitu pesat. Teknologi membuat jarak tak lagi jadi masalah dalam berkomunikasi. Internet tentu saja menjadi salah satu medianya. "Indonesia menempati peringkat 5 pengguna Twitter terbesar di dunia. Posisi Indonesia hanya kalah dari USA, Brazil, Jepang dan Inggris,". Menurut data dari Webershandwick, perusahaan public relations dan pemberi layanan jasa komunikasi, untuk wilayah Indonesia ada sekitar 65 juta pengguna Facebook aktif. Sebanyak 33 juta pengguna aktif per harinya, 55 juta pengguna aktif yang memakai perangkat mobile dalam pengaksesannya per bulan dan sekitar 28 juta pengguna aktif yang memakai perangkat mobile per harinya. Pengguna Twitter, berdasarkan data PT Bakrie Telecom, memiliki 19,5 juta pengguna di Indonesia dari total 500 juta pengguna global. Twitter menjadi salah satu jejaring sosial paling besar di dunia sehingga mampu meraup keuntungan mencapai USD 145 juta. Produsen di jejaring sosial adalah orang-orang yang telah memproduksi sesuatu, baik tulisan di Blog, foto di Instagram, maupun mengupload video di Youtube.

Media massa pada masanya terutama koran cukup mendalam dalam mengulas berita, namun adakalanya ia mengabaikan berita dari aspek tertentu dan orang lebih menyukai film dokumenter atau sekarang yang disebut dengan web series.

Web Series adalah salah satu bentuk tontonan masyarakat modern masa kini. Konsep yang dimiliki ini mirip dengan program acara di televisi Indonesia namun hanya tayang durasi relatif lebih pendek 5-20 menit daripada tayangan di televisi pada umumnya. Pilihan acaranya web series bermacam-macam seperti sinetron atau FTV (Film Televisi seperti yang ada di televisi, vlog, tutorial hijab, memasak, make up bahkan masih banyak lagi. Web series biasanya mengikuti konsumen yang setiap kali tayang hanya seminggu sekali namun melihat kondisi waktu tayang dapat berubah tergantung situasi misalkan kendala yang membuat web series mundur waktu tayangnya.

Web series memilih penikmat yang dapat mengaksesnya melalui jaringan internet dengan menggunakan laptop, tablet atau smartphone. Web series merupakan produk televisi yang memanfaatkan jaringan bentuk media komunikasi yang menghasilkan edukasi baru untuk masyarakat masa kini.

Pengguna internet yang mengetahui bahwa internet sebagai tempat untuk melakukan mendapatkan informasi dengan efektif dan efisien. Para pendiri situs web series terus menerus memikirkan cara untuk mengembangkan situs website, mereka dengan menawarkan beragam jenis kebutuhan yang diperlukan oleh masyarakat, salah satunya adalah dengan tayangan-tayangan web series malam minngu miko, dokter online dan Kisah Carlo yang memiliki ruang Carlo sendiri di Rumah Sakit Carolus, Jl. Salemba Raya No.41, RT.3/RW.5, Paseban, Senen, Kota Jakarta Pusat, Daerah Khusus Ibukota Jakarta 10440 yang dikemas dalam bentuk iklan baik di media konvensional seperti televisi, cetak, radio maupun media baru seperti sosial media dan jejaring sosial lainnya salah satunya adalah YouTube.

YouTube punya lebih dari satu miliar pengguna, hampir sepertiga dari semua pengguna internet dan setiap harinya orang menonton ratusan juta jam iklan di YouTube dan menghasikan miliaran kali penayangan. Di Indonesia, YouTube merupakan jejaring sosial ketiga yang paling sering dikunjungi 
setelah Facebook dan Instagram, dengan masing-masing persentase Facebook $54 \%$ yaitu sebanyak 71,6 juta user, kedua Instagram 15\% sebanyak 19,9 juta user dan ketiga adalah YouTube $11 \%$ sebanyak 14,5 juta user. (sumber: Youtube $)^{1}$

Web series Kisah Carlo cerita pendek yang berdurasi 20 menit 33 detik tersebut telah banyak memberikan edukasi mengenai penyakit kelamin bahkan penularannya dengan sangat detail, agar masyarakat lebih peduli dengan kesehatan. Kisah Carlo telah memberikan gambaran yang sangat mendetail dengan aktor-aktor yang baik dalam memerankan Kisah Carlo Episode 01 yang berjudul Pilot, menceritakan penularan virus AIDS/HIV dari berhubungan suami istri diperankan oleh (suami sebagai Surya, dan istri sebagai Maya) penyampaian naskah pada cerita tersebut dengan gimic muka dan komunikasi verbalnya telah menyampaikan bahayanya penularan $A I D S$, yang tanpa diketahui bahwa sang suami telah menularkan virus $A I D S$ yang sulit untuk disembuhkan tanpa diketahui istrinya.

Web Series Kisah Carlo telah hadir memberikan pesan moral bahwa pergaulan bebas dengan didukungnya media komunikasi dengan sangat mudah dan canggih tanpa kenal usia mudah di akses melalu channel youtube dengan memberikan kemudahan masyarakat yang masih menganggap tabu pendidikan seks diusia dini, bahayanya jika tanpa pengawasan orang tua usia remaja akan mudah terjerumus dan salah paham dalam mengartikan web series Kisah Carlo tersebut. Akan tetapi, kita juga tidak bisa mengabaikan dampak negatif dari munculnya situs web series Kisah Carlo, dampak negatif yang ditimbulkan adalah adanya perilaku menyimpang yang menciptakan gaya hidup bebas karena tertarik melihat dan ingin coba-coba untuk membuktikannya.

\footnotetext{
${ }^{1}$ Informasi penulis dapatkan dari Survei APJII 2016
}

Melihat persoalan yang begitu kompleks dan realitas yang terjadi pada jaman milenial saat ini yaitu penggunaan video yang menampilkan tanda serta penanda menjadi hal yang penting untuk tetap di bahas dari berbagai aspek maka dalam penelitian ini penulis memfokuskan masalah yang akan diteliti agar tidak keluar dari fokus permasalahan, yaitu dikaji pada Pemaknaan tanda dan penanda serta aspek Representasi pada Web Series Kisah Carlo Episode 01 Pilot di YouTube yang berdurasi 20 menit 33 detik.

\subsection{Tujuan}

Mengkaji dan menganalisis maksud dibalik Web Series Kisah Carlo Episode 01 Pilot di YouTube yang berdurasi 20 menit 33 detik yaitu:

1. Untuk mengetahui makna dan representasi kemanusiaan pada Web Series Kisah Carlo Episode 01 Pilot di Youtube.

2. Untuk memberikan pesan moral kepada penderita IMS.

3. Untuk memberikan edukasi yang jelas pada masyarakat terutama orang tua dalam mengawasi pergaulan anak pada Web Series Kisah Carlo Episode 01 Pilot di Youtube.

\subsection{Pembingkaian Teori dan kerangka pemikiran pada Penelitian. \\ 1.3.1 Pembingkaian teori semiotik Chrles Sanders Pierce}

Alex Sobur (2001) mengatakan dalam bukunya yang berjudul Analisis Teks Media, Semiotika atau semiologi merupakan terminologi yang merujuk pada ilmu yang sama. Istilah semiologi lebih banyak digunakan di Eropa, sedangkan semiotika lazim dipakai oleh ilmuan Amerika, Istilah kata semiologi lebih banyak di gunakan di Eropa, Sedangkan semiotika lazim dipakai oleh ilmuwan Amerika. Istilah kata berasal dari bahasa yunani semeion yang berarti 'tanda' atau 'sign' dalam bahasa inggris, yaitu ilmu yang 
mempelajari sistem tanda seperti bahasa, kode, sinyal, lambang dan sebagainya.

Dalam pengertian yang hampir sama, Charles Sanders Pierce menyebutkan bahwa semiotika adalah studi tentang bagaimana bentuk bentuk simbolik di inpretasikan. Kajian ilmiah mengenai perubahan makna. Secara substansia semiotika adalah kajian yang konsen dengan dua simbol.

semiotika Charles Sanders Peirce.

Bagi Pierce (Pateda, 2001: 44, dalam
Sobur, 2006:41) tanda "is something which stands to somebody for something in some respect or capacity." Sesuatu yang digunakan agar tanda bisa berfungsi, oleh Pierce disebut ground. Konsekuensinya, tanda (sign atau representnmen) selalu terdapat dalam hubungan triadik, yakni ground, object, dan interpretant.

\section{Gambar 3.1 Hubungan Tanda, Objek, dan Interpretan (Triangle of Meaning)}

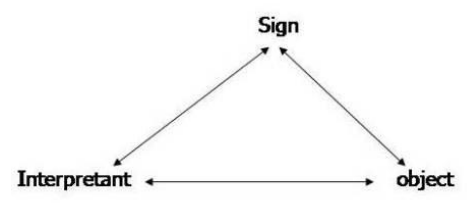

\section{Sumber: Kriyantono.2006. Teknik Praktis Riset Komunikasi. Hlm 266}

Atas dasar hubungan ini, Peirce mengadakan klasifikasi tanda. Tanda yang dikaitkan dengan ground dibaginya menjadi qualisign, sinsign dan legisign. (Sobur, 2013: 42)

a. Qualisign adalah kualitas yang ada pada tanda, misalnya kata-kata kasar, keras, lemah, lembut, merdu.

b. Sinsign adalah eksistensi aktual benda atau peristiwa yang ada pada tanda; misalnya kata kabur atau keruh yang ada pada urutan kata air sungai keruh yang menandakan bahwa ada hujan di hulu sungai.

c. Legisign adalah norma yang dikandung oleh tanda, misalnya rambu-rambu lalu lintas yang menandakan halha yang boleh atau tidak boleh dilakukan manusia.

\section{Gambar 3.2 Model Hubungan Triadik Peirce}

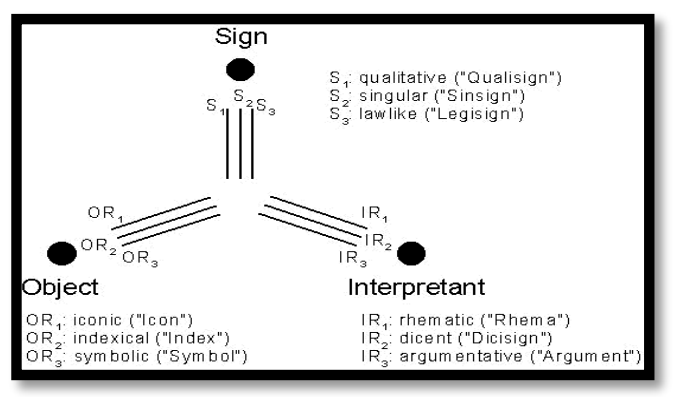

Sumber: digitalpeirce.fee.unicamp.br 
Berdasarkan berbagai klasifikasi tersebut, Peirce membagi tanda menjadi sepuluh jenis:

1. Rhematic Iconic Qualisign, yakni kualitas sejauh yang dimiliki tanda. Kata keras menunjukkan kualitas tanda. Misalnya, suaranya keras yang menandakan orang itu marah atau ada sesuatu yang diinginkan.

2. Rhematic Iconic Sinsign, yakni tanda yang memperlihatkan kemiripan. Contoh: foto, diagram, peta, dan tanda baca.

3. Rhematic Indexical Sinsign, yakni tanda berdasarkan pengalaman langsung, yang secara langsung menarik perhatian karena kehadirannya disebabkan oleh sesuatu. Contoh: pantai yang sering merenggut nyawa orang yang mandi di situ akan dipasang bendera bergambar tengkorak yang bermakna berbahaya, dilarang mandi disini.

4. Dicent Indexical Sinsign, yakni tanda yang memberikan informasi tentang sesuatu. Misalnya, tanda larangan yang terdapat di pintu masuk sebuah kantor.

5. Rhematic Iconic Legisign, yakni tanda yang menginformasikan norma atau hukum. Misalnya, rambu lalu lintas. 6. Rhematic Indexical Legisign, yakni tanda yang mengacu kepada objek tertentu, misalnya kata ganti penunjuk. Seseorang bertanya, "Mana buku itu?" dan dijawab, "Itu!"

7. Dicent Indexical Legisign, yakni tanda yang bermakna informasi dan menunjuk subjek informasi. Tanda berupa lampu merah yang berputar-putar di atas mobil ambulans menandakan ada orang sakit atau orang yang celaka yang tengah dilarikan ke rumah sakit.

8. Rhematic Symbol atau Symbolic Rheme Legisign, yakni tanda yang dihubungkan dengan objeknya melalui asosiasi ide umum. Misalnya, kita melihat gambar harimau. Lantas kita katakan, 'harimau Mengapa kita katakan demikian, karena ada asosiasi antara gambar dengan benda atau hewan yang kita lihat yang namanya harimau.

9. Dicent Symbolic Legisign atau proposition (proposisi) adalah tanda yang langsung menghubungkan dengan objek melalui asosiasi dalam otak. Kalau seseorang berkata, "Pergi!" penafsiran kita langsung berasosiasi pada otak, dan sertamerta kita pergi. Padahal proposisi yang kita dengar hanya kata. Kata-kata yang kita gunakan yang membentuk kalimat, semuanya adalah proposisi yang mengandung makna yang berasosiasi di dalam otak. Otak secara otomatis dan cepat menafsirkan proposisi itu, dan seseorang segera menetapkan pilihan atau sikap.

10. Argument Symbolic

Legisign, yakni tanda yang merupakan iferens seseorang terhadap sesuatu berdasarkan alasann tertentu. Seseorang berkata, "Gelap." Orang itu berkata gelap sebab ia menilai ruang itu cocok dikatakan gelap. Dengan demikian argumen merupakan tanda yang berisi penilaian atau alasan, mengapa seseorang berkata begitu. tentu saja penilaian tersebut mengandung kebenaran. 


\subsubsection{Kerangka pemikiran}

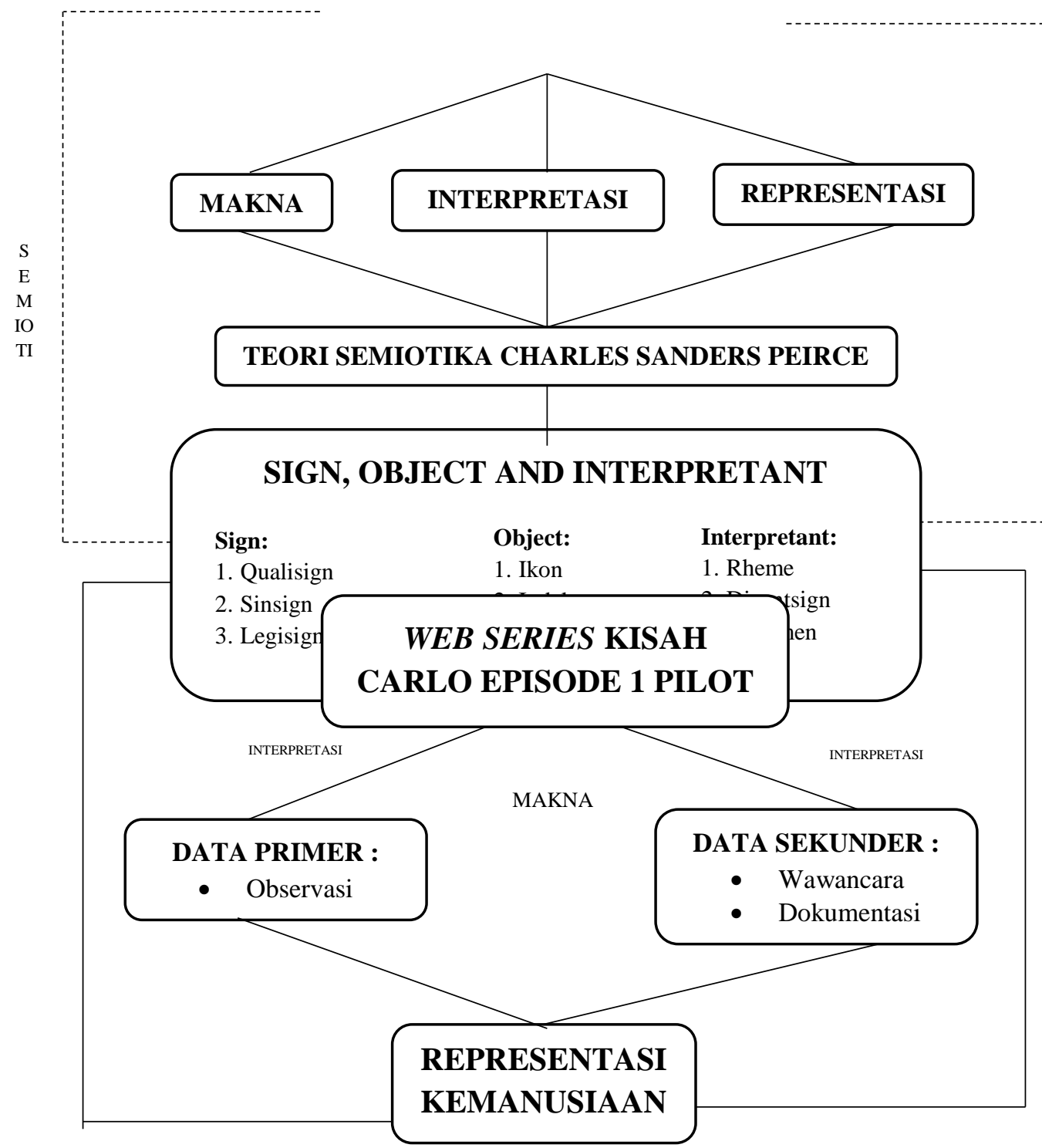

\section{PEMBAHASAN}

Sebuah rangkaian Web Series yang terdiri dari 10 episode, tiap episode dirilis setiap dua minggu sekali di Youtube dimulai dari tanggal 1 Desember 2015. Tiap Episode berdurasi 10-20 menit. Ruang Carlo adalah pusat pelayanan dan pengobatan bagi para penderita HIV/AIDS di Rumah Sakit St. Carolus, Jakarta. Cerita berpusat pada dinamika kehidupan di Ruang Carlo, para pekerja disana serta para pasien. Tentang pergulatan, tantangan dan harapan mereka, webseries ini dibuat untuk kepentingan non-komersil dalam rangka menyebarkan kepedulian, kewaspadaan dan edukasi terhadap penyakit HIV/AIDS bagi masyarakat melalui media elektronik.

Kemanusiaan adalah tentang nilai-nilai yang dianut oleh manusia dalam kaitan hubungannya dengan sesama manusia, seperti toleransi, welas-asih,cinta-kasih, tolongmenolong, gotong-royong, mendahulukan kepentingan umum, dan 
banyak lainnya, semua nilai-nilai itu adalah antara manusia dengan manusia.

Memang di web series kisah carlo nilai kemanusiaan yang sangat terlihat adalah saling merangkul, memberikan motivasi dan saling suport, penulispun juga berfikir demikian, karena mereka yang menderita penyakit tersebut sangat butuh suport terutama suport dari keluarga, karena keluarga merupakan faktor yang sangat berpengaruh terhadap mental si penderita, dan juga tidak semua penderita HIV/AIDS itu adalah orang yang nakal, atau memiliki kebiasaan buruk, jadi sudah sepantasnya kita manusia memang harus saling merangkul, saling memotivasi dan berguna untuk manusia lainnya.

Selanjutnya mengenai pesan moral pada web series kisah carlo, untuk moral sendiri itu memiliki pengertian yaitu perbuatan / tingkah laku / ucapan seseorang dalam berinteraksi dengan manusia. apabila yang dilakukan seseorang itu sesuai dengan nilai rasa yang berlaku di masyarakat tersebut dan dapat diterima serta menyenangkan lingkungan masyarakatnya, maka orang itu dinilai memiliki moral yang baik, begitu juga sebaliknya.

\section{Deskripsi dan Narasi Web Series} Kisah Carlo Episode 1

1. Scene Pertama berdurasi (02.40 03.10). adalah tampilan pertama dalam visualisasi nilai kemanusiaan, dimana ada nenek dan kakek yang sedang berjalan di lorong rumah sakit sambil mendorong cucunya yang terlihat sangat lemas dikursi roda. Latar belakang terlihat seperti lorong rumah sakit dan di sisi kanan gambar terdapat orang yang sedang duduk menunggu sesuatu, lalu disisi kiri gambar seperti orang degan urusannya sendiri.

a. Nilai Kemanusiaan

Discene pertama ini nilai kemanusiaan yang terkandung adalah kepeduliaan, saling membantu seperti seorang kakek dan nenek yang terlihat bagaimana mereka merawat cucunya yang terkena HIV/AIDS mereka merwatnya dengan penuh kasih sayang.

b. Pesan Moral

Pesan moral yang terkandung pada scene pertama ini adalah bagaimana kita berguna dan bermanfaat untuk orang lain terutama keluarga sendiri, karena discene ditampilkan seorang kakek dan nenek yang merawat cucunya dengan penuh kesabaran agar cucunya dapat hidup sehat.

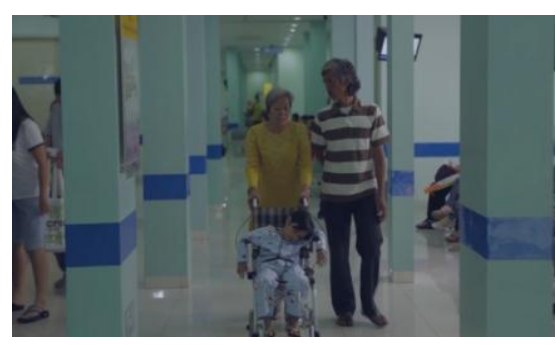

(Sumber: Olahan Penulis)

Gambar 4.7 scene nilai kemanusiaan 1

2. Scene kedua berdurasi dari $(04.00$ - 05.28). Dalam scene kedua ini merupakan tampilan kedua visualisasi nilai kemanusiaan, dalam scene ini terdapat seorang suster rs yang sedang berbicara serius dengan pasiennya disebuah ruangan yaitu seorang anak perempuan yang terlihat nakal dan anak perempuan tersebut diantar oleh ibunya untuk berobat.

a. Nilai Kemanusiaan

Saling memberitahu, saling mengingatkan terlihat jelas pada scene ini merupakan suatu bentuk kepedulian suster terhadap pasiennya, walaupun pasiennya susah untuk diatur dan tidak mau mendengarkan namun suster tetap mengingatkan dengan baik. 


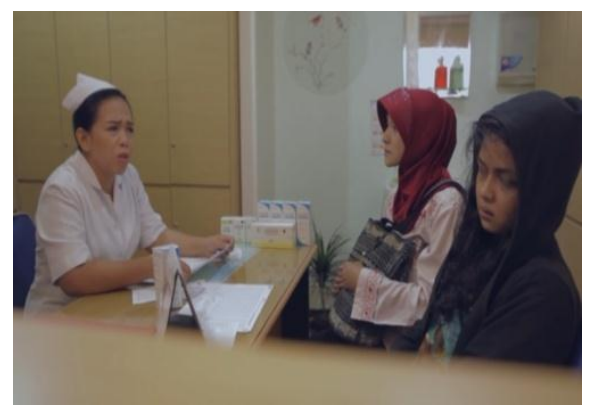

(Sumber: Olahan Penulis)

Gambar 4.8 scene nilai kemanusiaan

2

3. Scene ketiga (07.18 - 07.51). discene ini terdapat wanita dengan gaya masa kini yang sedang berbicara berdua dengan seorang suster di suatu ruangan konsultasi, wanita dengan gaya kini tersebut terlihat sedikit canggung dan nsedang bingung, namun suster berusaha menenangkan.

a. Nilai Kemanusiaan

Nilai kemusiaan pada scene ini sama seperti scene 2 saling mengingatkan dan memberikan motivasi positif untuk perubahan pasien yang lebih baik, yaitu pada saat pasien berkata dia sudah tidak melayani om-om yang lain dan suster memberikan katakata positive yaitu "Bagus, suatu langkah besar sudah kamu ambil" dan menurut penulis kata-kata itu sangat memberikan pengaruh untuk mental pasien untuk bangkit.

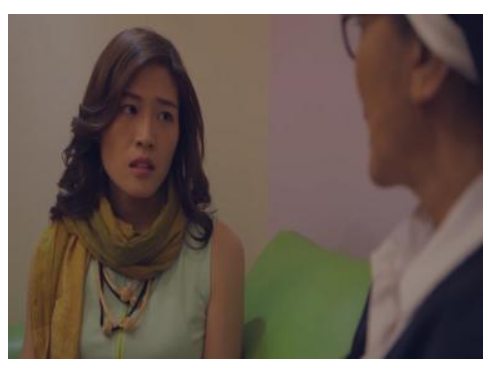

(Sumber: Olahan Penulis)

Gambar 4.9 scene nilai kemanusiaan 3

\section{Analisis Trikotomi dan Tabel Identifikasi}

Tabel 4.2. Identifikasi Secara Umum Ikon, Indeks, dan Simbol Dalam Web Series Kisah Carlo Episode 1 dimedia Sosial Youtube.

Sumber: Olahan Penulis

\begin{tabular}{|c|c|c|l|}
\hline NO & IDENTIFIKASI & ARTI & \multicolumn{1}{c|}{ TANDA } \\
\hline & & & 1. Kursi Roda \\
& & & 2. Lorong RS \\
& & & 3. Obat-obatan \\
& & & 4. Jilbab \\
& \multirow{3}{*}{ IKON } & Tanda yang & 5. Informasi minum aturan \\
& & muncul dari & obat \\
& & perwakilan fisik & 6. Syal \\
& & & 7. Kacamata \\
& & & 8. Pulpen \\
& & & 9. Buku Tulis \\
& & & 10. Kursi diruang tunggu \\
& & & 11. Informasi mengenai \\
\hline
\end{tabular}




\begin{tabular}{|c|c|c|c|}
\hline & & & $\begin{array}{l}\text { prosedur pelayanan dokter } \\
\text { 12. Sikap meminimalisir } \\
\text { kekhawatiran } \\
\text { 13. Sweater Rajut } \\
\text { 14. Motif Kupu-kupu } \\
\text { 15. Tas Wanita } \\
\text { 16. Minyak kayu putih } \\
\text { 17. Kertas hasil tes HIV/AIDS } \\
\text { 18. Jas Putih } \\
\text { 19. Bunga Matahari } \\
\text { 20. Informasi penanganan } \\
\text { HIV/AIDS }\end{array}$ \\
\hline 2 & INDEKS & $\begin{array}{c}\text { Tanda yang } \\
\text { muncul karena } \\
\text { sebab akibat }\end{array}$ & $\begin{array}{l}\text { 1. Kursi roda sebagai indeks } \\
\text { alat bantu jalan bagi orang } \\
\text { sakit } \\
\text { 2. Posisi duduk anak kecil } \\
\text { dikursi roda } \\
\text { 3. Jilbab sebagai indeks } \\
\text { wanita baik-baik } \\
\text { 4. Tatapan sinis anak } \\
\text { perempuan pada scene } 2 \\
\text { 5. Expresi wajah sinis } \\
\text { 6. Syal } \\
\text { 7. Kacamata } \\
\text { 8. Warna hijau } \\
\text { 9. Warna Putih } \\
\text { 10. Jas Putih } \\
\text { 11. Seragam putih } \\
\text { 12. Wajah pucat } \\
\text { 13. Bibir Pecah-pecah } \\
\text { 14. Mata celong } \\
\text { 15. Kacamata } \\
\text { 16. Minyak kayu putih } \\
\text { 17. Warna pink } \\
\text { 18. Tas wanita } \\
\text { 19. Motif kupu-kupu } \\
\text { 20. Waria } \\
\text { 21. Sweater rajut } \\
\text { 22. Kertas hasil tes HIV/AIDS } \\
\text { 23. Bunga Matahari } \\
\text { 24. Batuk-batuk }\end{array}$ \\
\hline
\end{tabular}




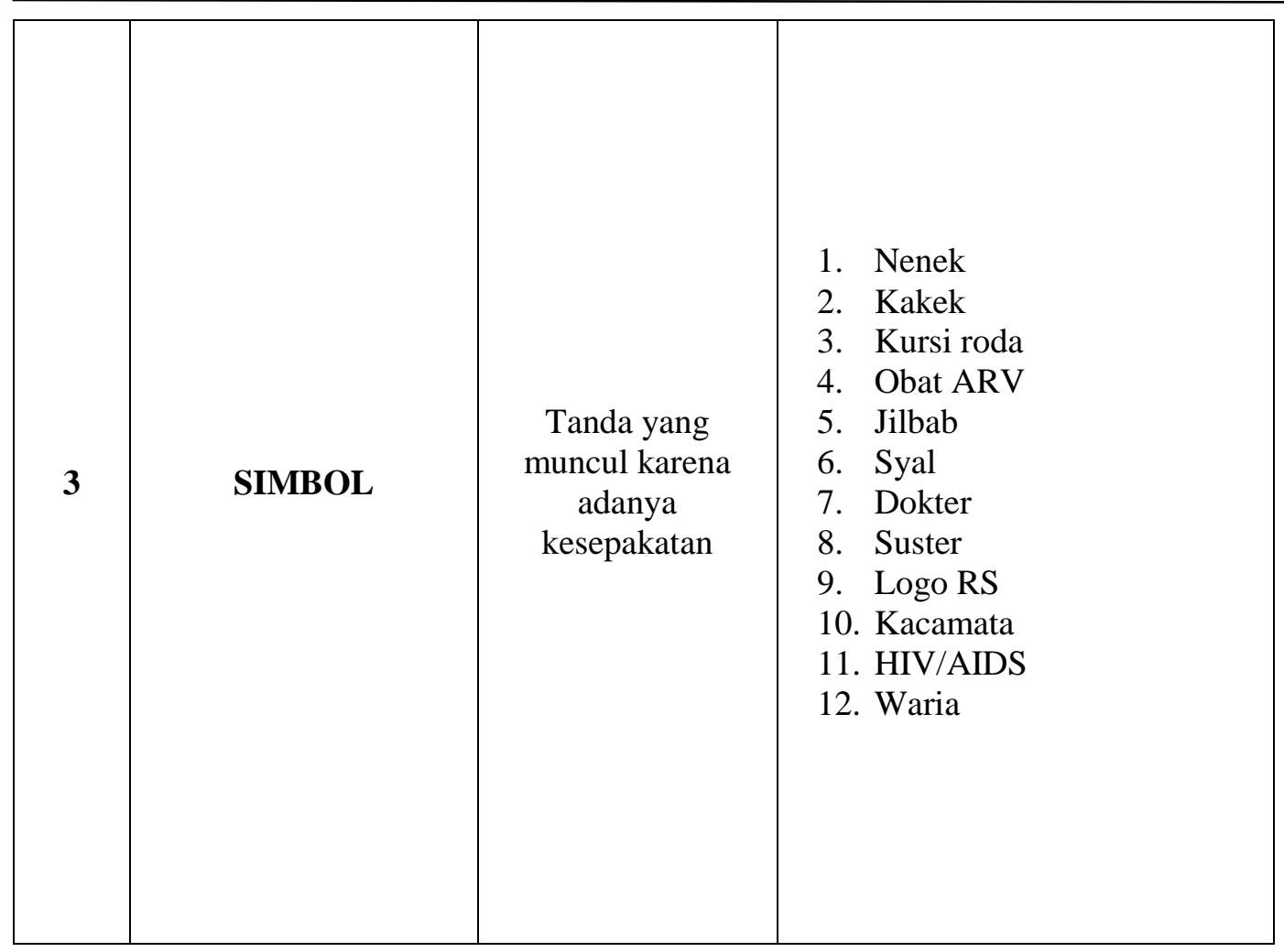

Berdasarkan identifikasi tanda ikon, indeks dan simbol diatas, peneliti akan menjelaskan lebih detail identifikasi tanda ikon, indeks dan simbol berdasarkan scene yang sudah peneliti uraikan sebelumnya. Berikut adalah penjelasannya.

Tabel 4.3. Identifikasi Tanda Ikon, Indeks, dan Simbol Setiap Scene Dalam Web Series Kisah Carlo Episode 1

\begin{tabular}{|c|c|c|c|}
\hline SCENE & IKON & INDEKS & SIMBOL \\
\hline Pertama & $\begin{array}{ll}\text { 1. } & \text { Kursi roda } \\
\text { 2. } & \text { Lorong Rumah } \\
& \text { Sakit } \\
\end{array}$ & $\begin{array}{ll}\text { 1. } & \text { Kursi roda } \\
\text { 2. } & \text { Posisi duduk anak } \\
\text { kecil }\end{array}$ & $\begin{array}{ll}\text { 1. } & \text { Nenek } \\
\text { 2. } & \text { Kakek } \\
\text { 3. } & \text { Kursi roda } \\
\end{array}$ \\
\hline Kedua & 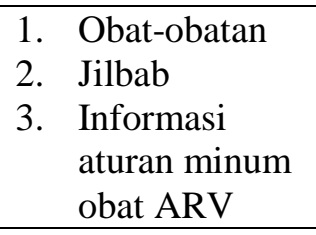 & $\begin{array}{ll}\text { 1. Jilbab } \\
\text { 2. Tatapan anak } \\
\text { perempuan } \\
\text { 3. Expresi wajah sinis } \\
\end{array}$ & $\begin{array}{ll}\text { 1. } & \text { Suster } \\
\text { 2. } & \text { Obat ARV } \\
\text { 3. } & \text { Jilbab }\end{array}$ \\
\hline Ketiga & $\begin{array}{ll}\text { 1. Syal } \\
\text { 2. Kacamata }\end{array}$ & $\begin{array}{ll}\text { 1. } & \text { Syal } \\
\text { 2. } & \text { Kacamata } \\
\text { 3. } & \text { Warna hijau }\end{array}$ & $\begin{array}{l}\text { 1. Suster } \\
\text { 2. Syal }\end{array}$ \\
\hline
\end{tabular}


Makna Tanda Ikon, Indeks, dan Simbol

1. Analisis Trikotomi,Makna,Tanda,Ikon, Indeks, dan Simbol Scene 1

Kebersamaan - Kegundahan - Mencari Solusi - Alat Bantu Jalan Orang

Sakit - Sedang Sakit - Kepedulian

Nilai Kemanusiaan

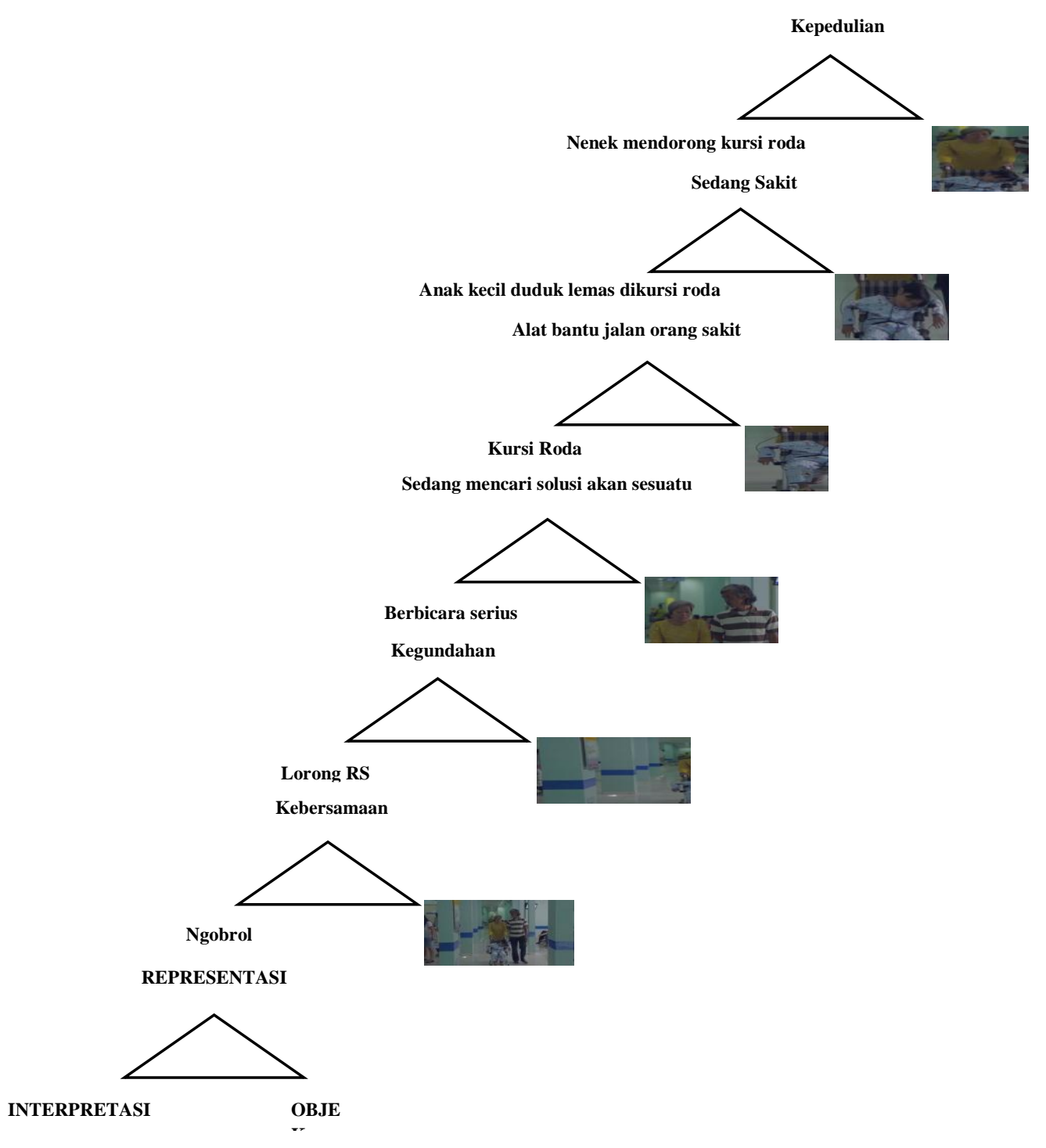

Sumber Olahan Penulis

Gambar 4.14 Analisis Trikotomi Scene 1 
a. Ikon

Tabel 4.3 Makna Tipe Tanda Ikon Dalam Scene 1 Web Series Kisah Carlo Episode

1.

\begin{tabular}{|c|c|c|c|}
\hline $\begin{array}{c}\mathbf{N} \\
\mathbf{O}\end{array}$ & Tanda & Objek & Interpretant \\
\hline 1. & Kursi roda & $\begin{array}{c}\text { Sama dengan } \\
\text { tanda }\end{array}$ & $\begin{array}{c}\text { Alat bantu yang digunakan oleh orang } \\
\text { yang mengalami kesulitan berjalan } \\
\text { menggunakan kaki, baik dikarenakan } \\
\text { oleh penyakit, cedera, maupun cacat. }\end{array}$ \\
\hline 32. & $\begin{array}{c}\text { Lorong Rumah } \\
\text { Sakit }\end{array}$ & $\begin{array}{c}\text { Sama dengan } \\
\text { tanda }\end{array}$ & $\begin{array}{c}\text { Jalan kecil dirumah sakit yang } \\
\text { menghubungkan satu tempat ketempat } \\
\text { lainnya dirumah sakit. }\end{array}$ \\
\hline
\end{tabular}

b. Indeks

Tabel 4.4 Makna Tipe Tanda Indeks Dalam Scene 1 Web Series

Kisah Carlo Episode 1

\begin{tabular}{|l|c|c|c|}
\hline NO & Tanda & Objek & Interpretant \\
\hline 1. & Kursi roda & $\begin{array}{c}\text { Merujuk pada } \\
\text { ra lelah atau } \\
\text { tidak mampu } \\
\text { berdiri lama }\end{array}$ & $\begin{array}{c}\text { Alat bantu yang digunakan oleh orang } \\
\text { yang mengalami kesulitan berjalan } \\
\text { menggunakan kaki, baik dikarenakan } \\
\text { oleh penyakit, cedera, maupun cacat. }\end{array}$ \\
\hline $\begin{array}{c}\text { 2. } \\
\text { Posisi duduk anak } \\
\text { kecil }\end{array}$ & Cara duduk & $\begin{array}{c}\text { Posisi duduk anak kecil discene ini } \\
\text { menunjukan bahwa anak tersebut memiliki } \\
\text { keadaan yang sangat lemas dan sedang } \\
\text { sakit parah. }\end{array}$ \\
\hline
\end{tabular}

\section{c. Simbol}

Tabel 4.5 Makna Tipe Tanda Simbol Dalam Scene 1 Web Series Kisah Carlo

Episode 1

\begin{tabular}{|c|l|l|l|}
\hline & \multicolumn{1}{|c|}{ Tanda } & \multicolumn{1}{c|}{ Objek } & \multicolumn{1}{c|}{ Interpretant } \\
\hline 1. & Nenek & $\begin{array}{l}\text { Makna penggunaan } \\
\text { talent } \text { seorang nenek. }\end{array}$ & $\begin{array}{l}\text { Wanita yang sudah tua dan sudah } \\
\text { berumur lanjut, dalam scene ini } \\
\text { nenek dengan pakaian sedikit lusuh } \\
\text { yang menandakan bahwa dia adalah } \\
\text { dari kalangan yang kurang mampu. }\end{array}$ \\
\hline 2. & Kakek & $\begin{array}{l}\text { Makna penggunaan } \\
\text { talent } \text { seorang kakek. }\end{array}$ & $\begin{array}{l}\text { Pria tua yang sudah berumur lanjut } \\
\text { dalam scene ii kakek dengan pakaian } \\
\text { yang sedikit lusuh menandakan dia } \\
\text { adalah dari kalangan yang kurang } \\
\text { mampu. }\end{array}$ \\
\hline 3. & Kursi roda & $\begin{array}{l}\text { Merujuk pada ra lelah } \\
\text { atau tidak mampu } \\
\text { berdiri lama. }\end{array}$ & $\begin{array}{l}\text { Alat bantu yang digunakan oleh orang } \\
\text { yang mengalami kesulitan Berjalan } \\
\text { menggunakan kaki, baik dikarenakan } \\
\text { penyakit,cedera atau cacat. }\end{array}$ \\
\hline
\end{tabular}


Analisis Trikotomi,Makna,Tanda,Ikon, Indeks, dan Simbol Scene 2

Kebersamaan - Makanan untuk kesembuhan - Keangkuhan Kegundahan - Keangkuhan - Kepedulian Nilai Kemanusiaan

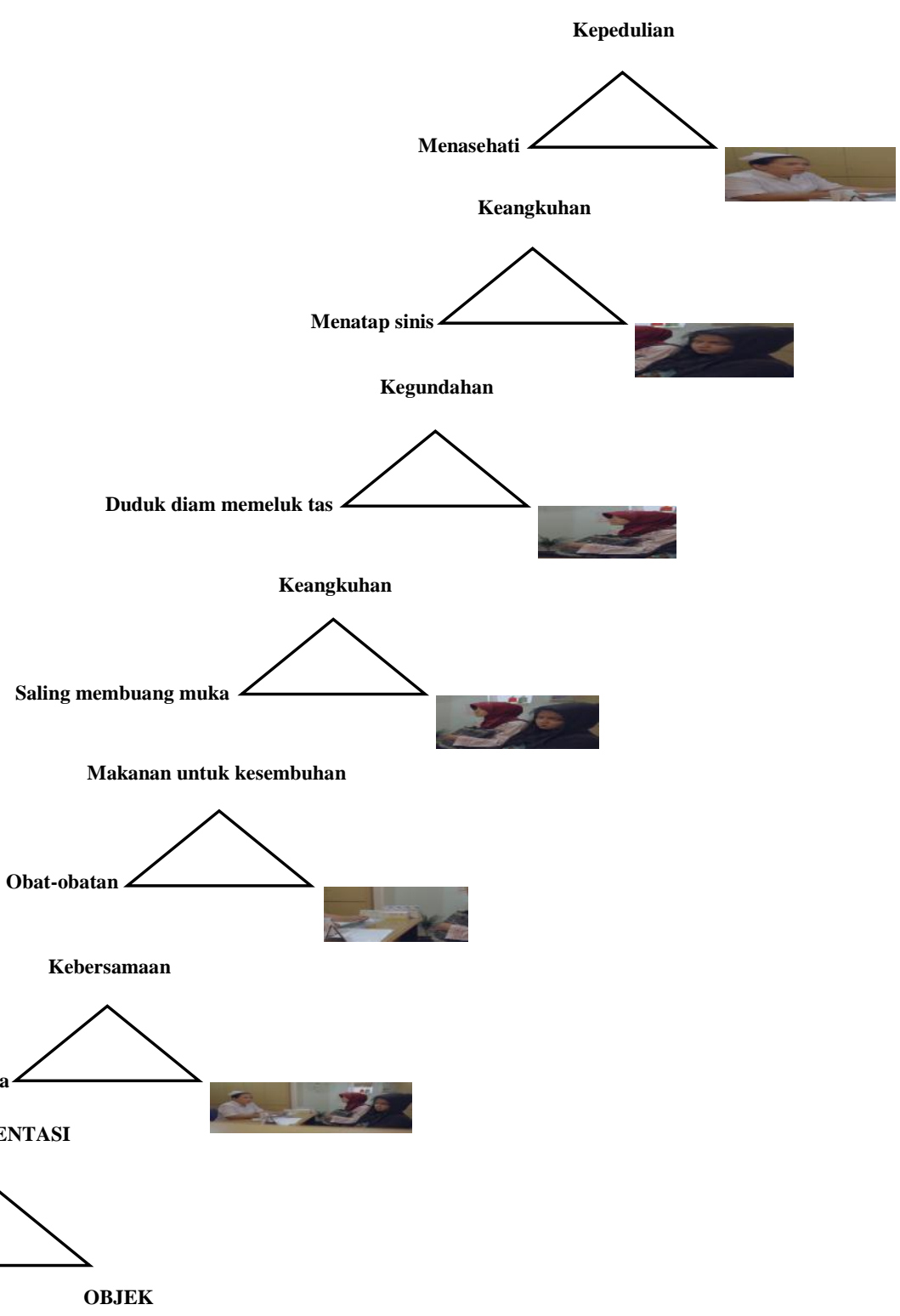

Sumber: Olahan Penulis

Gambar 4.15 Analisi Trikotomi Scene 2 
a. Ikon

Tabel 4.6 Makna Tipe Tanda Ikon Dalam Scene 2 Web Series Kisah Carlo Episode 1.

\begin{tabular}{|c|l|l|l|}
\hline & \multicolumn{1}{|c|}{ Tanda } & \multicolumn{1}{c|}{ Objek } & \multicolumn{1}{c|}{ Interpretant } \\
\hline 1. & Obat-obatan & $\begin{array}{l}\text { Sama dengan } \\
\text { tanda }\end{array}$ & $\begin{array}{l}\text { Obat ialah suatu bahan atau paduan } \\
\text { bahan-bahan yang dimaksudkan untuk } \\
\text { digunakan dalam } \\
\text { menetapkan diagnosis,mencegah,men } \\
\text { gurangkan,menghilangkan,menyembu } \\
\text { hkan penyakit atau gejala penyakit }\end{array}$ \\
\hline 2. & Jilbab & $\begin{array}{l}\text { Sama dengan } \\
\text { tanda }\end{array}$ & $\begin{array}{l}\text { lusana muslim terusan panjang } \\
\text { kecuali wajah yang biasa dikenakan } \\
\text { oleh para wanita muslim. }\end{array}$ \\
\hline 3. & $\begin{array}{l}\text { Informasi aturan } \\
\text { minukm obat } \\
\text { ARV }\end{array}$ & $\begin{array}{l}\text { Sama dengan } \\
\text { tanda }\end{array}$ & $\begin{array}{l}\text { MIV/AIDS tidak boleh telat minum } \\
\text { ARV karena akan membuat virus } \\
\text { HIV/AIDS akan selalu aktif. }\end{array}$ \\
\hline
\end{tabular}

b. Indeks

Tabel 4.7 Makna Tipe Tanda Indeks Dalam Scene 2 Web Series Kisah Carlo Episode 1

\begin{tabular}{|l|l|l|l|}
\hline & \multicolumn{1}{|c|}{ Tanda } & \multicolumn{1}{c|}{ Objek } & \multicolumn{1}{c|}{ Interpretant } \\
\hline 1. & Jilbab & $\begin{array}{l}\text { Merujuk pada } \\
\text { wanita yang } \\
\text { berperangai } \\
\text { baik. }\end{array}$ & $\begin{array}{l}\text { busana muslim terusan panjang } \\
\text { menutupi seluruh bagian kepala } \\
\text { kecuali wajah yang biasa dikenakan } \\
\text { oleh para wanita muslim., biasanya } \\
\text { wanita yang menggunakan jilbab } \\
\text { memiliki perangai baik dan taat. }\end{array}$ \\
\hline 2. & Tatapan sinis & $\begin{array}{l}\text { Adanya respon } \\
\text { pupil dalam } \\
\text { menanggapi } \\
\text { situasi. }\end{array}$ & $\begin{array}{l}\text { Seorang yang menatap sinis } \\
\text { seseorang, yang menandakan } \\
\text { ketidaksetujuan dan ketidaksukaan } \\
\text { mengenai suster tersebut. }\end{array}$ \\
\hline 3. & $\begin{array}{l}\text { Expresi wajah } \\
\text { sinis }\end{array}$ & $\begin{array}{l}\text { Merujuk pada } \\
\text { berfungsinya } \\
\text { syaraf wajah }\end{array}$ & $\begin{array}{l}\text { Expresi wajah seorang yang memiliki } \\
\text { arti ketidaksukaan dan ingin } \\
\text { menentang. }\end{array}$ \\
\hline
\end{tabular}

\section{c. Simbol}

Tabel 4.8 Makna Tipe Tanda Simbol Dalam Scene 2 Web Series isah Carlo Episode 1

\begin{tabular}{|c|l|l|l|}
\hline & \multicolumn{1}{|c|}{ Tanda } & \multicolumn{1}{c|}{ Objek } & \multicolumn{1}{c|}{ Interpretant } \\
\hline 1. & Suster & $\begin{array}{l}\text { Makna } \\
\text { penggunaan } \\
\text { talent seorang } \\
\text { suster. }\end{array}$ & $\begin{array}{l}\text { Merupakan perawat wanita yang } \\
\text { mengurusi pasien, dan mengontrol } \\
\text { pasien dibawah naungan dokter. }\end{array}$ \\
\hline 2. & Obat ARV & $\begin{array}{l}\text { Makna obat } \\
\text { ARV }\end{array}$ & $\begin{array}{l}\text { obat antiretroviral (ARV). ARV tidak } \\
\text { membunuh virus HIV/AIDS. Namun, }\end{array}$ \\
\hline
\end{tabular}




\begin{tabular}{|c|l|l|l|}
\hline & & $\begin{array}{l}\text { ART dapat melambatkan pertumbuhan } \\
\text { virus HIV/AIDS. }\end{array}$ \\
\hline 3. & Jilbab & Makna jilbab & $\begin{array}{l}\text { Menandakan wanita taat, wanita agamis } \\
\text { dan baik-baik. Pada scene ini jilbab } \\
\text { menandakan sebagai wanita penyabar. }\end{array}$ \\
\hline
\end{tabular}

Analisis Trikotomi,Makna,Tanda,Ikon, Indeks, dan Simbol Scene 3

Kebersamaan - Berusaha untuk paham - Butuh dikasihani Kedinginan - Kurang Sehat - Penglihatan kurang bagus Kepedulian Nilai Kemanusiaan

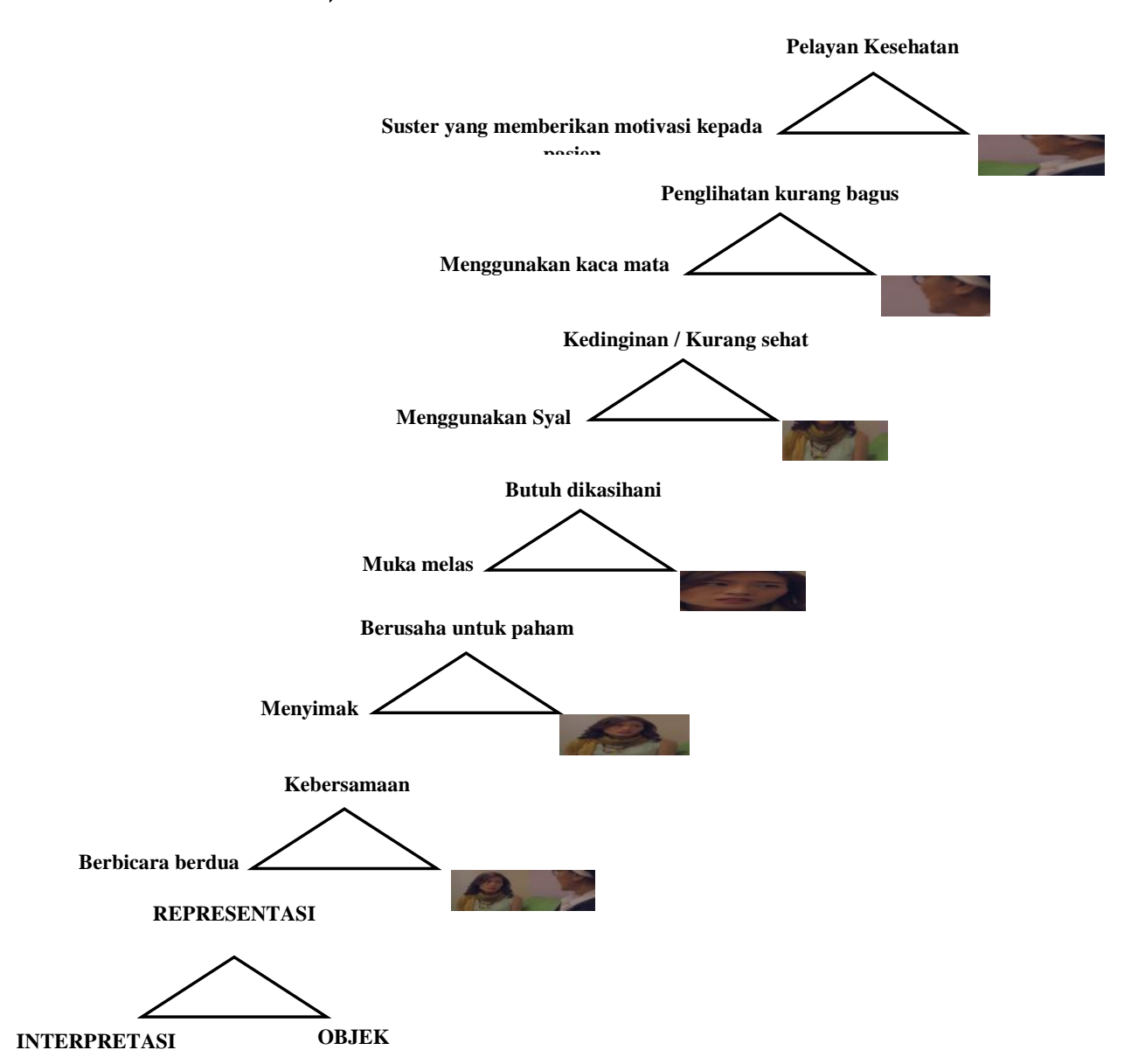

Sumber Olahan Penulis

Gambar 4.16 Analisi Trikotomi Scene 3 
a. Ikon

Tabel 4.9 Makna Tipe Tanda Ikon Dalam Scene 3 Web Series Kisah Carlo

Episode 1.

\begin{tabular}{|c|c|c|c|}
\hline & Tanda & Objek & Interpretant \\
\hline 1. & Syal & $\begin{array}{l}\text { Sama dengan } \\
\text { tanda }\end{array}$ & $\begin{array}{l}\text { adalah kain pakaian sederhana, } \\
\text { dipakai secara longgar di atas } \\
\text { bahu, tubuh bagian atas dan } \\
\text { lengan, kadang-kadang juga di atas } \\
\text { kepala. Biasanya berupa sehelai } \\
\text { kain persegi panjang, sering dilipat } \\
\text { untuk membuat segitiga tetapi juga } \\
\text { bisa memang berbentuk segitiga } \\
\text { dari awal. }\end{array}$ \\
\hline 2. & Kacamata & $\begin{array}{l}\text { Sama dengan } \\
\text { tanda }\end{array}$ & $\begin{array}{l}\text { lensa tipis untuk mata guna } \\
\text { menormalkan dan mempertajam } \\
\text { penglihatan (ada yang berangka } \\
\text { dan ada yang tidak). Sekarang } \\
\text { selain menjadi alat bantu } \\
\text { penglihatan, }\end{array}$ \\
\hline
\end{tabular}

\section{b. Indeks}

Tabel 4.10 Makna Tipe Tanda Indeks Dalam Scene 3 Web Series Kisah Carlo Episode 1

\begin{tabular}{|l|l|l|l|}
\hline & \multicolumn{1}{|c|}{ Tanda } & \multicolumn{1}{c|}{ Objek } & \multicolumn{1}{c|}{ Interpretant } \\
\hline 1. & Syal & $\begin{array}{l}\text { Merujuk pada } \\
\text { kain } \\
\text { penghangat } \\
\text { tubuh yang } \\
\text { dipakai dileher }\end{array}$ & $\begin{array}{l}\text { Penderita HIV/AIDS menggunakan } \\
\text { syal biasanya untuk menghangatkan } \\
\text { tubuhnya. }\end{array}$ \\
\hline 2. & Kacamata & $\begin{array}{l}\text { Lensa untuk } \\
\text { membantu } \\
\text { orang melihat. }\end{array}$ & $\begin{array}{l}\text { lensa tipis untuk mata guna } \\
\text { menormalkan dan mempertajam } \\
\text { penglihatan ada yang berangka dan } \\
\text { ada yang tidak) Sekarang selain } \\
\text { menjadi alat bantu penglihatan, }\end{array}$ \\
\hline 3. & Warna hijau & $\begin{array}{l}\text { Merujuk pada } \\
\text { kesuburan }\end{array}$ & $\begin{array}{l}\text { Warna hijau bagi sebagian orang } \\
\text { bukan hanya memiliki arti } \\
\text { kesuburan tapi Kesegaran, } \\
\text { Kedamaian dan Keseimbangan }\end{array}$ \\
\hline
\end{tabular}

\section{c. Simbol}

Tabel 4.11 Makna Tipe Tanda Simbol Dalam Scene 3 Web Series isah Carlo Episode 1

\begin{tabular}{|c|l|l|l|}
\hline & \multicolumn{1}{|c|}{ Tanda } & \multicolumn{1}{c|}{ Objek } & \multicolumn{1}{c|}{ Interpretant } \\
\hline 1. & Suster & $\begin{array}{l}\text { Makna } \\
\text { penggunaan } \\
\text { talent } \text { seorang } \\
\text { suster. }\end{array}$ & $\begin{array}{l}\text { Merupakan perawat wanita yang } \\
\text { mengurusi pasien, dan mengontrol } \\
\text { pasien dibawah naungan dokter. }\end{array}$ \\
\hline 2. & Syal & Makna Syal & Untuk penghangat tubuh, \\
\hline
\end{tabular}




\begin{tabular}{|l|l|l|}
\hline & & $\begin{array}{l}\text { melindungi angin masuk kedalam } \\
\text { tubuh melalui leher. }\end{array}$ \\
\hline
\end{tabular}

\section{SIMPULAN}

Dalam penelitian berjudul
"REPRESENTASI
KEMANUSIAAN WEB SERIES
KISAH CARLO “ ini ada tiga hasil
yang peneliti uraikan dalam pembahasan di bab sebelumnya yaitu (1) makna dan representasi kemanusiaan pada Web Series Kisah Carlo Episode 01 Pilot di Youtube; (2) pesan moral yang diberikan pada Web Series Kisah Carlo Episode 01 Pilot di Youtube untuk penderita IMS (Infeksi Menular Seksual); (3) peran aktor dalam mengedukasi masyarakat mengenai IMS (Infeksi Menular Seksual) melalui Web Series Kisah Carlo Episode 01 Pilot di Youtube.

Makna dan representasi yang terkandung dalm web series kisah carlo episode 1 adalah bahwa kita sesama manusia harus saling tolong menolong dan saling mengingatkan dalam kebaikan, menolong dan membantu sesama manusia dengan ikhlas tanpa melihat latarbelakang orang yang kita tolong seperti apa, dan web series kisah carlo episode 1 ini juga menjelaskan tentang cara penularan HIV/AIDS, bahwa penularan HIV/AIDS tidak semudah yang difikirkan, penularan HIV/AIDS itu terjadi jika ada kontak darah dengan penderita dan darah penderita masuk kedalam tubuh kita, berhubungan badan dengan penderita, menggunakan jarum suntik secara bergantian dengan pederita, atau menerima donor darah dari penderita. Jadi, virus HIV/AIDS tidak akan menular jika kita berdekatan dengan penderita, satu sendok makan dengan penderita, berpelukan langsung dengan penderita serta berciuman dengan penderitapun itu tidak akan menularkan virusnya.

Manfaat diharapkan masyarakat dapat memanfaatkan dengan bijak media massa atau komunikasi untuk mendapatkan edukasi yang lebih bijak dan mendidik untuk perkembangan anak terutama pada pergaulannya, melalui media komunikasi RS CAROLUS berusaha memberikan sumbangan pemikiran edukasi melalui film pendek yang berdurasi \pm 20 menit mengenai penyakit IMS (Infeksi Menular Seksual) melalui Web Series Kisah Carlo Episode 01 Pilot di Youtube, RS CAROLUS telah berusaha memberikan sarana edukasi untuk masyarakat agar menjadi lebih bijak dalam menggunakan media massa di dunia ilmu komunikasi dengan film pendek yang berdurasi \pm 20 menit tersebut diharapkan dapat memberikan edukasi melalui aktor dan aktris yang memerankan Kisah Carlo Episode 01 Pilot diharapkan pesan moral tersampaikan dengan baik untuk masyarakat terutama untuk usia remaja.

Film pendek ini sangat tepat untuk dijadikan edukasi, dan untuk pendidikan seks hal tersebut penting, supaya film yang bernilai edukasi bukan lagi dianggap suatu hal yang tabu, sehingga banyak masyarakat dapat menjadi lebih selektif untuk bahan tontonan dikalangan remaja yang menuju dewasa secara mandiri dan membuka pemahaman yang lebih positif yang akan berdampak pada prilaku masyarakat tersebut. Sehingga dengan adanyaa penanyangan Web Series Kisah Carlo Episode 01 Pilot di Youtube untuk penderita IMS (Infeksi Menular Seksual) yang berdurasi \pm 20 menit diharapkan ilmu komunikasi (IT) dapat memberikan pencerahan melalui pengalaman-pengalaman para aktor dalam penyampaian pesan moral kepada masyarakat sehingga masyarakat dapat lebih bijak bergaul dengan cara yang lebih positif.

\section{DAFTAR PUSTAKA} Afrizal, M. P. K. (2014). Sebuah Upaya
Mendukung Penggunaan Penelitian
Kualitatif Dalam Berbagai Disiplin 
Ilmu. Jakarta: Pt Raja Grafindo Persada.

Agus, S. (2006). Teori dan Paradigma Penelitian Sosial. Yogyakarta: Tiara Wacana.

Bungin, B. (2007). Analisis data penelitian kualitatif. PT RajaGrafindo Persada.

Depdiknas, Pusat Bahasa. "Kamus besar bahasa Indonesia." Edisi Ketiga. Jakarta: Balai Pustaka (2002).

Hankins, C., Coutlee, F., Lapointe, N., Simard, P., Tran, T., Samson, J., \& Hum, L. (1999). Prevalence of risk factors associated with human papillomavirus infection in women living with HIV. Canadian Medical Association Journal, 160(2), 185-191.

Hovland, C. I., Janis, I. L., \& Kelley, H. H. (1953). Communication and persuasion; psychological studies of opinion change.

Hutapea, Edison, 2018, Modul Metode Penelitian Komunikasi, Pengertian Kualitatif: .45

Kulasingam, S. L., Hughes, J. P., Kiviat, N. B., Mao, C., Weiss, N. S., Kuypers, J. M., \& Koutsky, L. A. (2002). Evaluation of human papillomavirus testing in primary screening for cervical abnormalities: comparison of sensitivity, specificity, and frequency of referral. Jama, 288(14), 1749-1757.

Littlejo hn Stephen, W., \& Foss Karen, A. (2011). Teori komunikasi (Edisi 9). Jakarta: Salemba Humanika.

Miller, K. (2005). Communication theories. USA: Macgraw-Hill.

Moleong, J. (2010). Lexy, Metode Penelitian Kualitatif, PT. Remaja Rosdakarya Bandung.

Moleong, J. (2014). Lexy, Metodologi Penelitian kualitatif, Penerbit PT. Remaja Rosdakarya bandung.

Mulyana, D. (2008). Solatun, Metode Penelitian Komunikasi, Bandung: PT. Remaja Rosda Karya.

Mulyana, R. (2004). Mengartikulasikan pendidikan nilai. Alfabeta.

Nurgiyantoro, Burhan. Penilaian Pembelajaran Sastra Berbasis
Kompetensi. Yogyakarta: BPFE, 2010.

Sobur, A. (2001). Analisis teks media: suatu pengantar untuk analisis wacana, analisis semiotik dan analisis framing. Remaja Rosdakarya.

Sobur, A. (2013). Filsafat komunikasi tradisi dan metode fenomenologi. Bandung: Remaja Rosdakarya.

Sujarweni, V. W. (2014). Metodologi penelitian. Yogyakarta: Pustaka Baru.

Sun, X. W., Kuhn, L., Ellerbrock, T. V., Chiasson, M. A., Bush, T. J., \& Wright Jr, T. C. (1997). Human papillomavirus infection in women infected with the human immunodeficiency virus. New England Journal of Medicine, 337(19), 1343-1349.

Tanudyaya, F. K., Rahardjo, E., Bollen, L. J., Madjid, N., Daili, S. F., Priohutomo, S., ... \& Mamahit, E. R. S. (2010). Prevalence of sexually transmitted infections and sexual risk behavior among female sex workers in nine provinces in Indonesia, 2005. Southeast Asian Journal of Tropical Medicine and Public Health, 41(2), 463.

Wen, L. M., Estcourt, C. S., Simpson, J. M., \& Mindel, A. (1999). Risk factors for the acquisition of genital warts: are condoms protective?. Sexually Transmitted Infections, 75(5), 312316.

West, R., \& Turner, L. H. (2008). Pengantar teori Komunikasi: Analisis 156 dan Aplikasi, Buku 1 edisi ke-3, Terjemahan Maria Natalia Damayanti Maer. Jakarta: Salemba Humanika.

Wibowo, S. W. Indiwan,(2013). Semiotika Komunikasi-Aplikasi Praktis Bagi Penelitian dan Skripsi Komunikasi.

Zubier, F. (2003). Kondilomata Akuminata. In S. F. Daili, W. I. Makes, F. Zubier, \& J. Judanarso (Eds.), Penyakit Menular Seksual (pp. 125-130). Jakarta: Balai Penerbit FKUI. 